Supporting Information containing 17 pages, 12 figures and 3 tables to accompany manuscript titled

\title{
A Modified Double Potential Step Chronoamperometry (DPSC) Method for As(III) Electro-oxidation and Concomitant As(V) Adsorption from Groundwaters
}

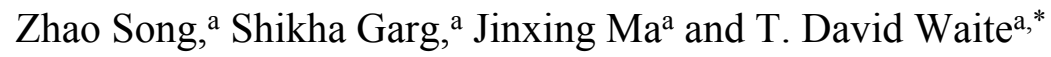 \\ ${ }^{\text {a } U N S W}$ Water Research Centre, School of Civil and Environmental Engineering, The \\ University of New South Wales, Sydney, NSW 2052, Australia
}




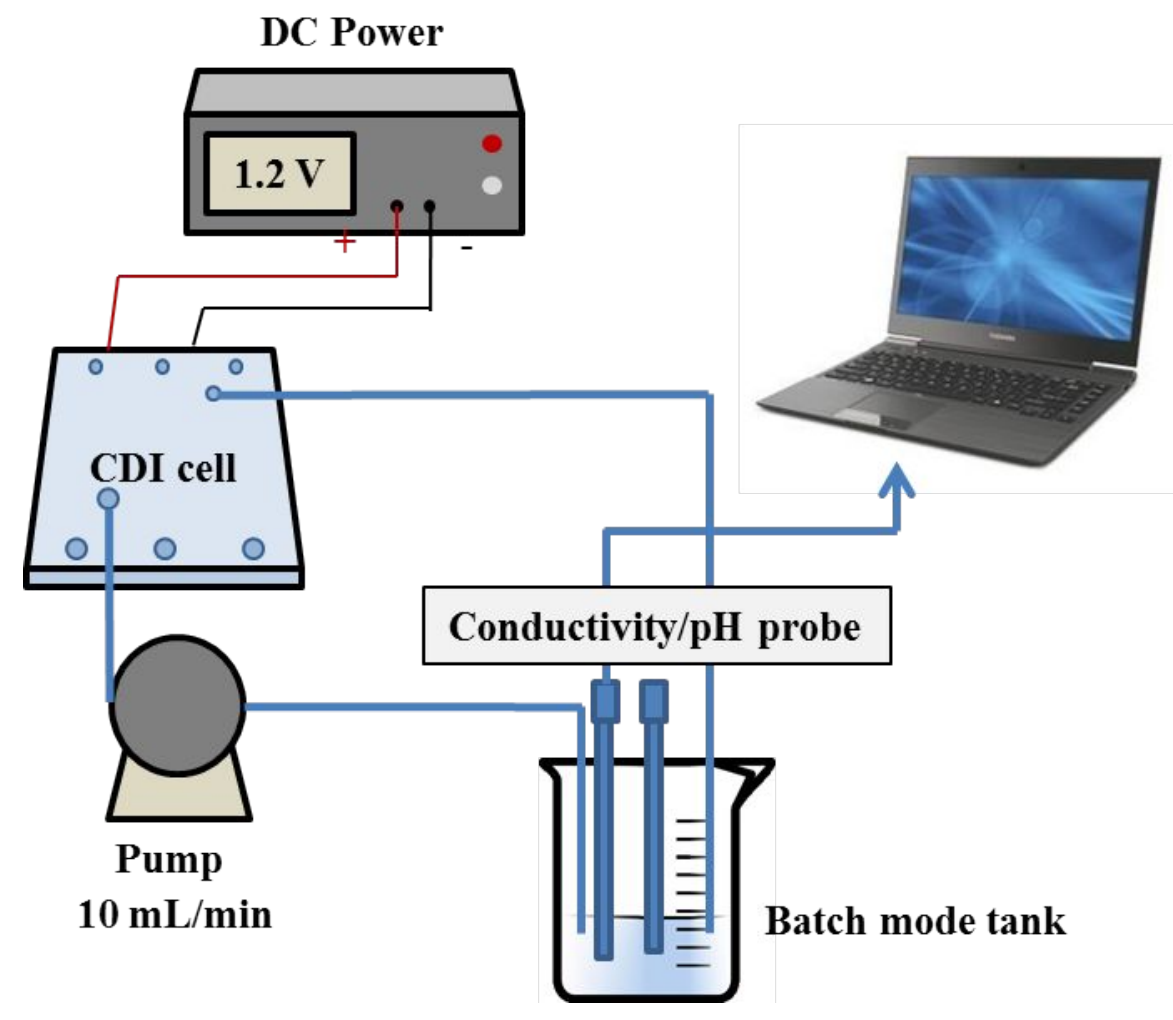

Figure S1. DPSC experimental setup

\section{S1.1 Calculation of electrode potential of the $\mathrm{Ag} / \mathrm{AgCl}$ reference electrode}

The electrode potential of $\mathrm{Ag} / \mathrm{AgCl}$ at a given $\mathrm{NaCl}$ concentration was calculated using eq. $\mathrm{S} 1$. Furthermore, a correction factor of $-0.07 \mathrm{~V}$ was applied to account for the difference in standard electrode potential of commercial $\mathrm{Ag} / \mathrm{AgCl}$ electrode and the self-made $\mathrm{Ag} / \mathrm{AgCl}$ electrode used here.

$$
E=E_{0}+0.059 \log \frac{K_{s p}}{\left[C l^{-}\right]}
$$

When $5 \mathrm{mM} \mathrm{NaCl}$ is used as electrolyte

$$
E=-0.07+0.799+0.059 \log \frac{1.8 \times 10^{-10}}{5 \times 10^{-3}}=0.29 \mathrm{~V}
$$


Table S1. LC isocratic method and ICP-MS operating parameters.

\begin{tabular}{cc}
\hline Parameter & Setting \\
\hline Mobile Phase & $10 \mathrm{mM}$ Ammonium Nitrate and \\
Flow Rate & (dibasic) \\
& $0.6 \mathrm{~mL} / \mathrm{min}$ \\
Column & Anion Exchange, Hamilton PRP- \\
X100, $4.1 \mathrm{~mm}$ i.d. $\times 250 \mathrm{~mm}, 10 \mu \mathrm{m}$ \\
Column Temperature & Ambient \\
Autosampler Flush & 6.2 \\
Solvent & $5 \%$ Methanol/95\% DI Type I Water \\
Sample Injection Volume & $100 \mu \mathrm{L}$ \\
Total Analysis Time & $8 \mathrm{~min}$ \\
\hline RF Power & $1500 \mathrm{w}$ \\
Plasma Ar Flow & $15 \mathrm{~L} / \mathrm{min}$ \\
Nebulizer Ar Flow & $1 \mathrm{~L} / \mathrm{min}$ \\
Aux. Ar Flow & $1 \mathrm{~L} / \mathrm{min}$ \\
Monitored Ion m/z & $75(75 \mathrm{As})$ \\
He gas Flow & $0.35 \mathrm{~mL} / \mathrm{min}$ \\
\hline &
\end{tabular}




\section{S2: Additional experimental results}
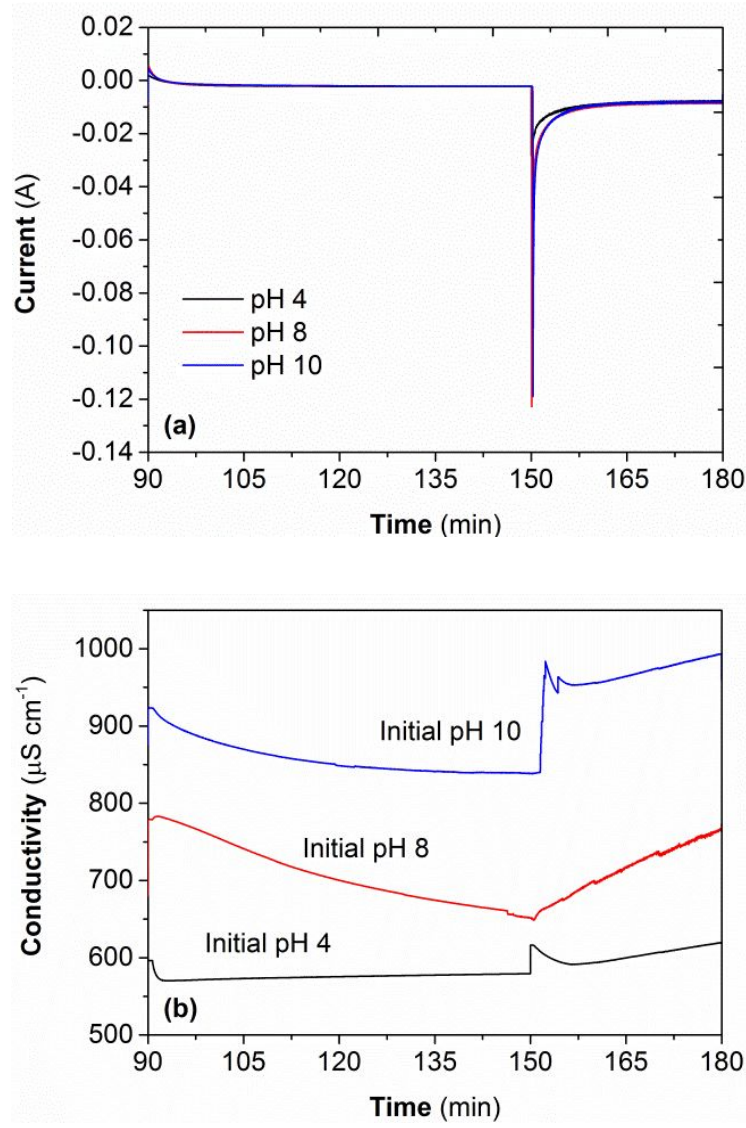

Figure S2. Changes in (a) current and (b) conductivity when the modified DPSC commenced with initial $\mathrm{pH} 4,8$ and 10. Experimental conditions: the feed solution contained $C_{0}=150 \mu \mathrm{g}$ $\mathrm{L}^{-1} \mathrm{As}(\mathrm{V})$ and $5 \mathrm{mM} \mathrm{NaCl}$. The initial $\mathrm{pHs}$ of 4,8 and 10 were respectively controlled by addition of $\mathrm{HCl}(<0.1 \mathrm{mM}), 2 \mathrm{mM} \mathrm{NaHCO}$, and $1 \mathrm{mM} \mathrm{NaHCO}_{3}$ and $1 \mathrm{mM} \mathrm{Na}_{2} \mathrm{CO}_{3} .1 .2 \mathrm{~V}$ was applied at the first step for $60 \mathrm{~min}$ followed by $-1.2 \mathrm{~V}$ for $30 \mathrm{~min}$. 

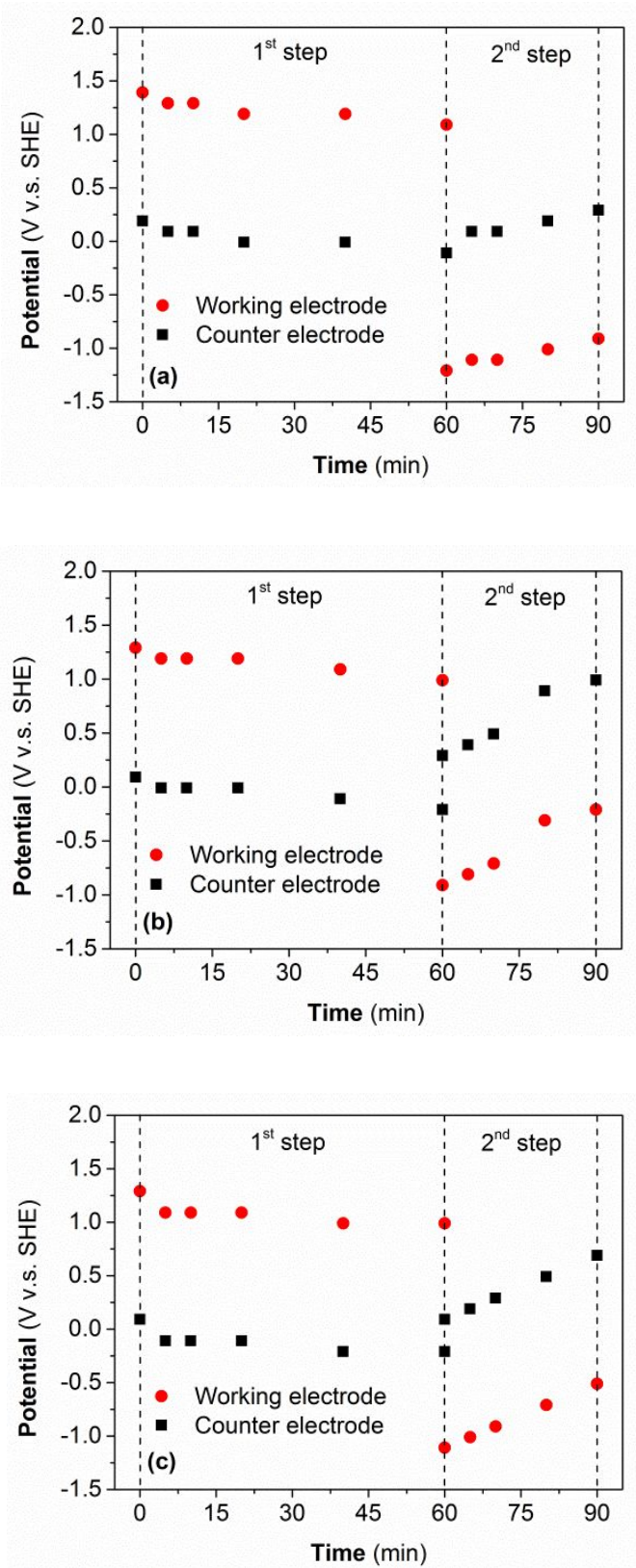

Figure S3. Changes in the potentials of working electrode and counter electrode versus standard hydrogen electrode (SHE) during As(III) removal at initial pH (a) 4, (b) 8 and (c) 10 during the first step and second step. Experimental conditions: the feed solution contained $C_{0}$ $=150 \mu \mathrm{g} \mathrm{L}^{-1} \mathrm{As}(\mathrm{V})$ and $5 \mathrm{mM} \mathrm{NaCl}$. The initial $\mathrm{pHs}$ of 4,8 and 10 were respectively controlled by addition of $\mathrm{HCl}(<0.1 \mathrm{mM}), 2 \mathrm{mM} \mathrm{NaHCO}_{3}$, and $1 \mathrm{mM} \mathrm{NaHCO}_{3}$ and $1 \mathrm{mM} \mathrm{Na}_{2} \mathrm{CO}_{3} .1 .2$ $\mathrm{V}$ was applied at the first step for $60 \mathrm{~min}$ followed by $-1.2 \mathrm{~V}$ for $30 \mathrm{~min}$. 


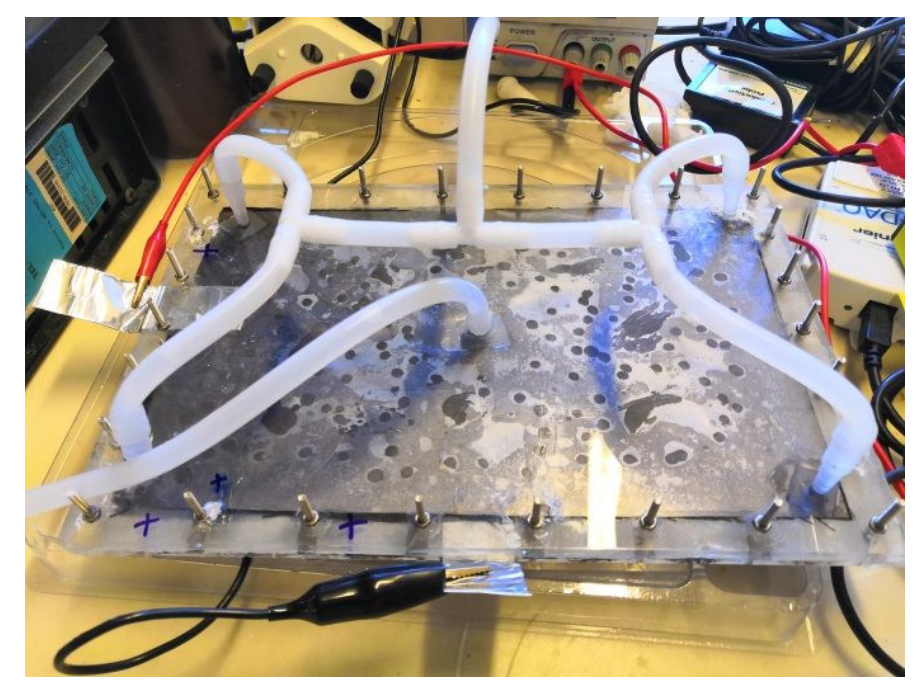

Figure S4. The $3^{\text {rd }}$ electrochemical cell with the electrode area of $27 \mathrm{~cm} \times 17 \mathrm{~cm}$.

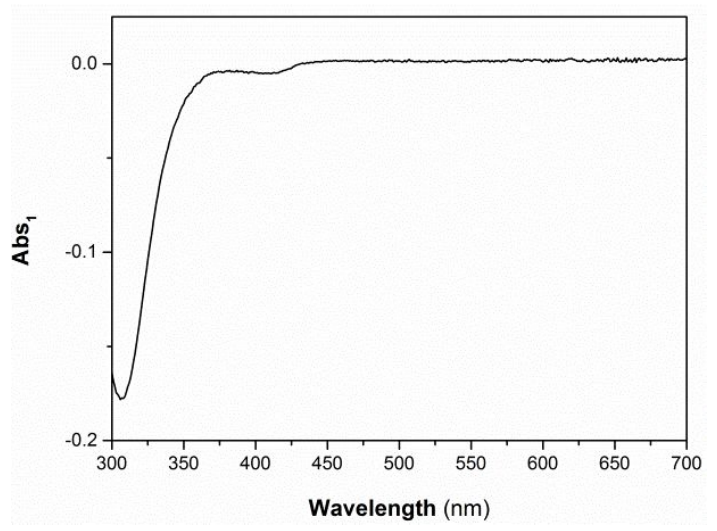

Figure S5. Measured absorbance $\mathrm{A}_{1}$ corresponding to $\mathrm{OCl}^{-}$formation in the experimental solution when the modified DPSC commenced with initial $\mathrm{pH} 8$ at $1.2 \mathrm{~V}$ after 60 -min adsorption. Experimental conditions: the feed solution contained $C_{0}=150 \mu \mathrm{g} \mathrm{L}^{-1} \mathrm{As}(\mathrm{III})$ and $5 \mathrm{mM} \mathrm{NaCl}$. 

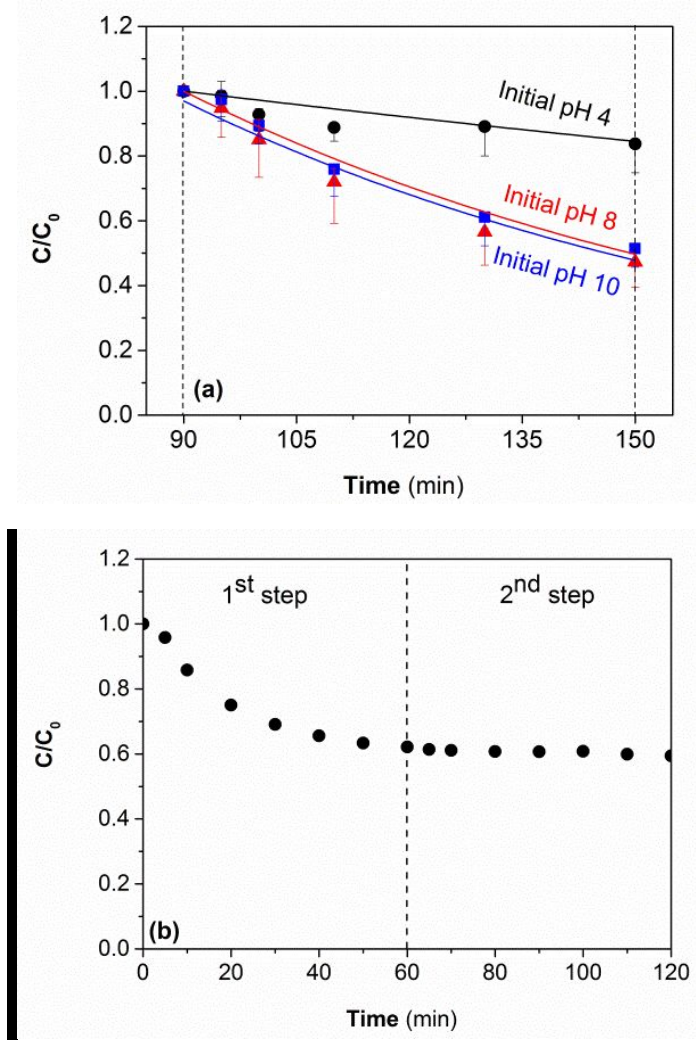

Figure S6. (a) Changes in aqueous $\mathrm{As}(\mathrm{V})$ concentrations when the modified DPSC commenced with initial pHs of 4,8 and 10. Experimental conditions: the feed solution contained $C_{0}=150 \mu \mathrm{g} \mathrm{L}{ }^{-1} \mathrm{As}(\mathrm{V})$ and $5 \mathrm{mM} \mathrm{NaCl}$. The initial pHs of 4, 8 and 10 were respectively controlled by addition of $\mathrm{HCl}(<0.1 \mathrm{mM}), 2 \mathrm{mM} \mathrm{NaHCO}_{3}$, and $1 \mathrm{mM} \mathrm{NaHCO} \mathrm{NaH}_{3}$ and $1 \mathrm{mM} \mathrm{Na}_{2} \mathrm{CO}_{3}$. No voltage was applied. (b) Changes in aqueous $\mathrm{As}(\mathrm{V})$ concentrations when the modified DPSC commenced with initial $\mathrm{pH}$ 4. Experimental conditions: the feed solution contained $C_{0}=150 \mu \mathrm{g} \mathrm{L}^{-1} \mathrm{As}(\mathrm{V})$ and $5 \mathrm{mM} \mathrm{NaCl} .1 .2 \mathrm{~V}$ was applied at the first step for $60 \mathrm{~min}$ followed by $0 \mathrm{~V}$ for $30 \mathrm{~min}$. 

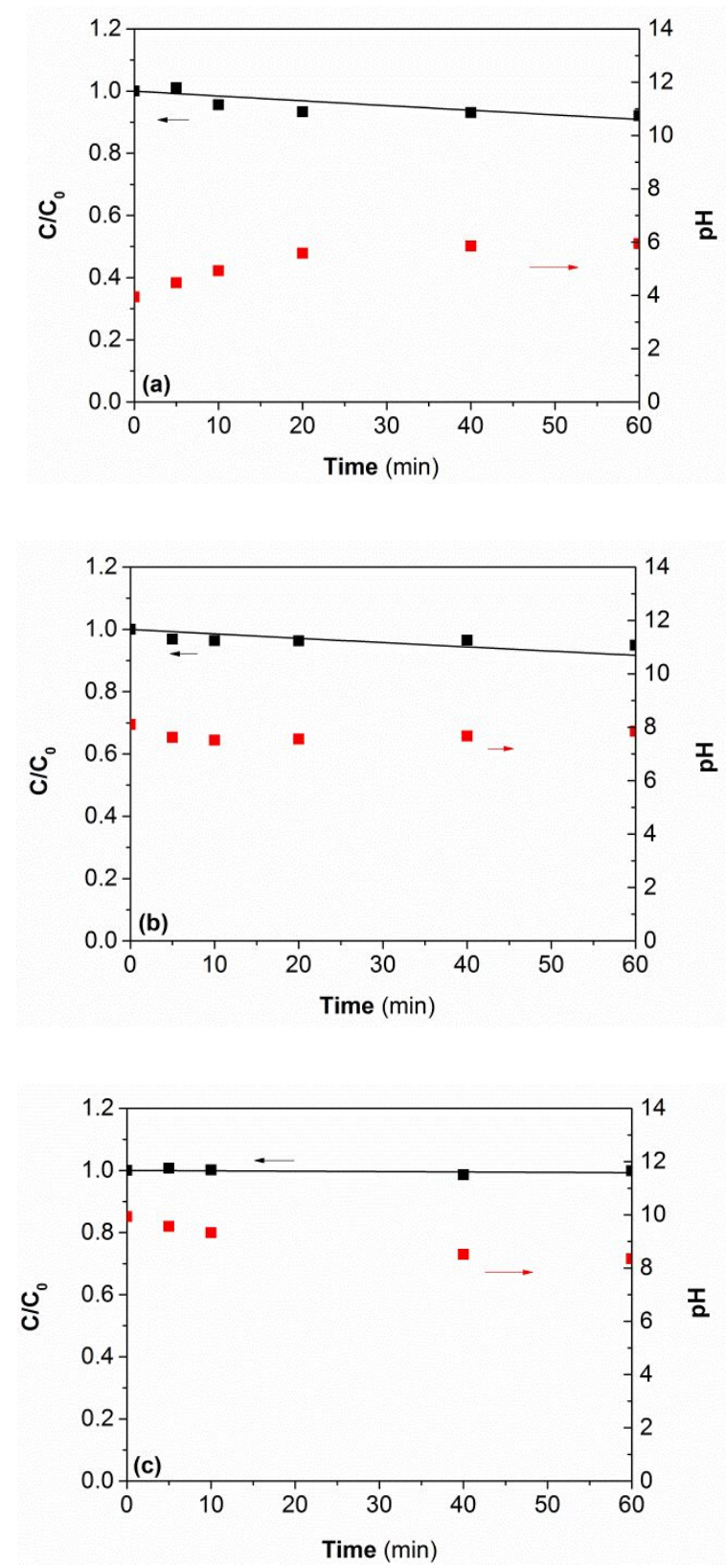

Figure S7. Changes in total As concentration (black squares) and $\mathrm{pH}$ (red circles) when the modified DPSC commenced with initial (a) $\mathrm{pH}$ 4, (b) 8 and (c) 10. Experimental conditions: the feed solution contained $C_{0}=150 \mu \mathrm{g} \mathrm{L}^{-1} \mathrm{As}(\mathrm{III})$ and $5 \mathrm{mM} \mathrm{NaCl}$. The initial $\mathrm{pH} \mathrm{4,} 8$ and 10 were respectively controlled by addition of $\mathrm{HCl}(<0.1 \mathrm{mM}), 2 \mathrm{mM} \mathrm{NaHCO}_{3}$, and $1 \mathrm{mM}$ $\mathrm{NaHCO}_{3}$ and $1 \mathrm{mM} \mathrm{Na}_{2} \mathrm{CO}_{3}$ ). No voltage was applied. 


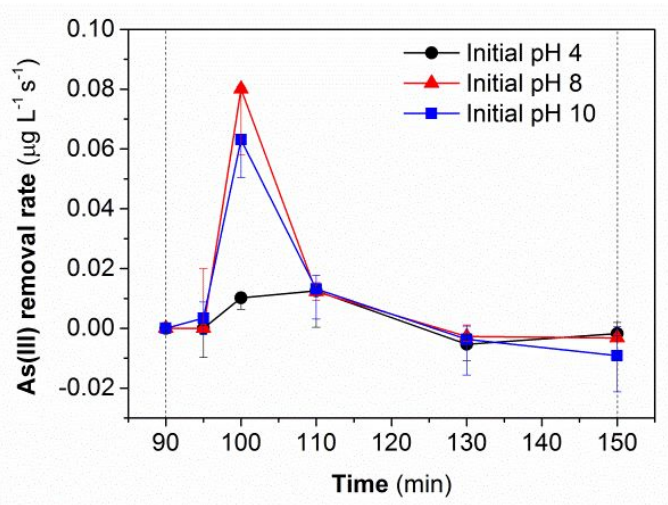

Figure S8. Changes in measured As(III) removal rate with time in the DPSC setup at varying $\mathrm{pH}$ conditions. Experimental conditions: the feed solution contained $C_{0}=150 \mu \mathrm{g} \mathrm{L}^{-1} \mathrm{As}(\mathrm{III})$ and $5 \mathrm{mM} \mathrm{NaCl}$. The initial $\mathrm{pH} \mathrm{4,8}$ and 10 were respectively controlled by addition of $\mathrm{HCl}$ $(<0.1 \mathrm{mM}), 2 \mathrm{mM} \mathrm{NaHCO}$, and $1 \mathrm{mM} \mathrm{NaHCO}_{3}$ and $\left.1 \mathrm{mM} \mathrm{Na}_{2} \mathrm{CO}_{3}\right)$.
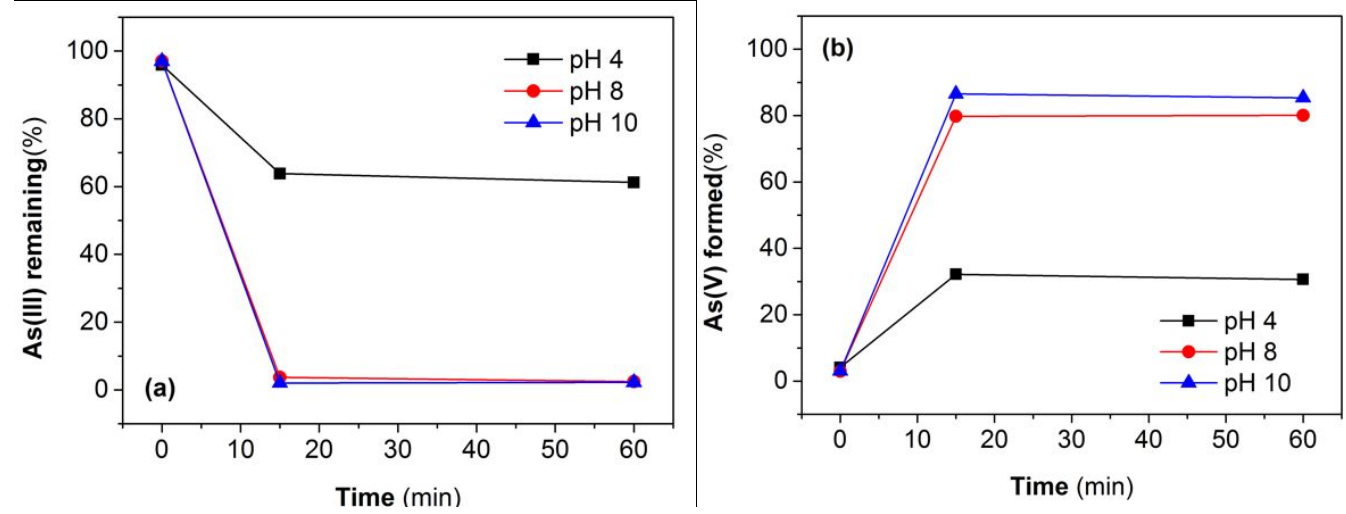

Figure S9 (a) \% of As(III) remaining (b) \% As(V) formed on As(III) oxidation during 60 mins when $150 \mu \mathrm{g} \mathrm{L}^{-1} \mathrm{As}(\mathrm{III})$ is added to $\mathrm{pH} 4,8$ and 10 solution containing $160 \mu \mathrm{M} \mathrm{H}_{2} \mathrm{O}_{2}$ 

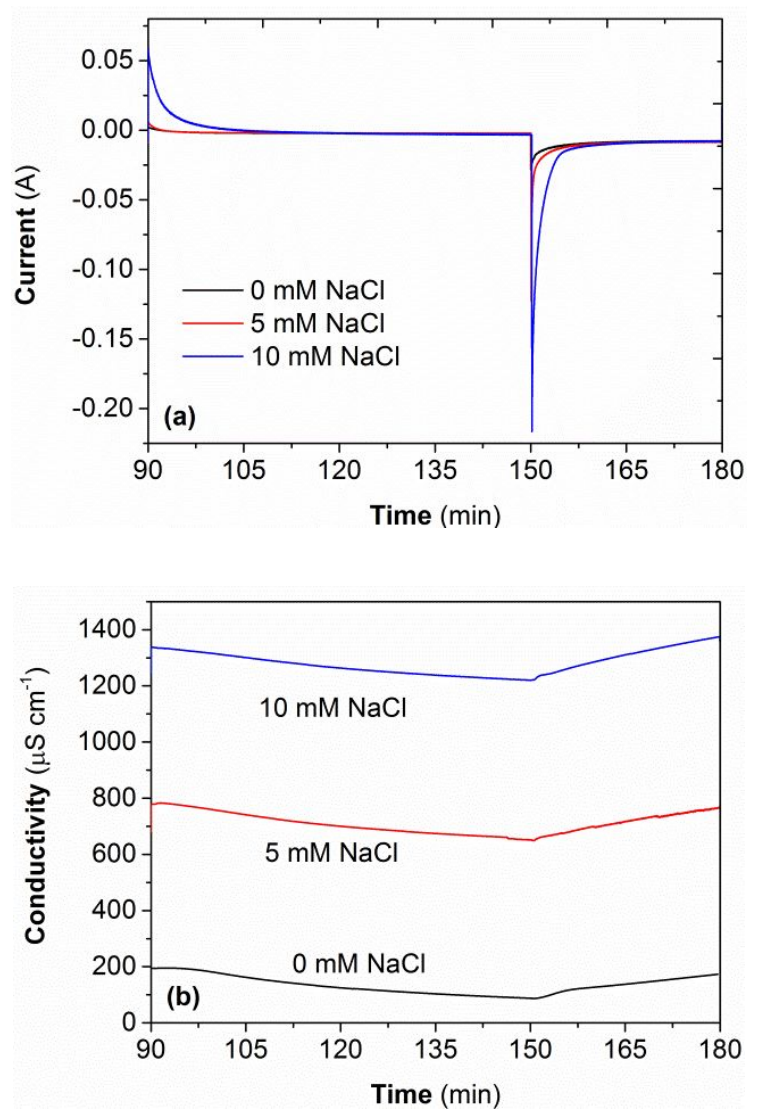

Figure S10. Changes in (a) current and (b) conductivity when the modified DPSC commenced with initial $\mathrm{pH} 8$ and $0,5 \mathrm{mM}$ and $10 \mathrm{mM} \mathrm{NaCl}$. Experimental conditions: the feed solution contained $C_{0}=150 \mu \mathrm{g} \mathrm{L}{ }^{-1} \mathrm{As}(\mathrm{III}) .1 .2 \mathrm{~V}$ was applied at the first step for $60 \mathrm{~min}$ followed by $-1.2 \mathrm{~V}$ for $30 \mathrm{~min}$.

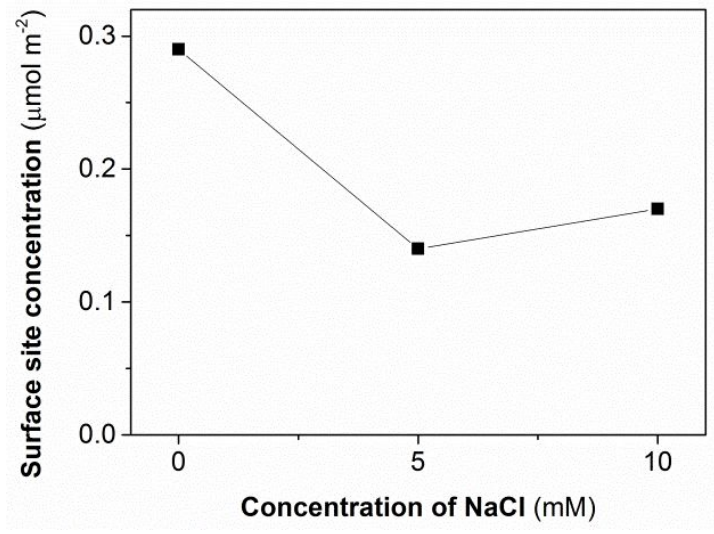

Figure S11. Surface site concentration available for As adsorption in the presence of varying $\mathrm{NaCl}$ concentration. (Surface site concentration: $\mathrm{C}_{S}=(\Delta C \times V) / A$ where $\Delta \mathrm{C}$ is the change in aqueous $\mathrm{As}(\mathrm{III})$ concentration; $\mathrm{V}$ is the volume of the batch, $60 \mathrm{~mL}$; $\mathrm{A}$ is the surface area of the working electrode). 


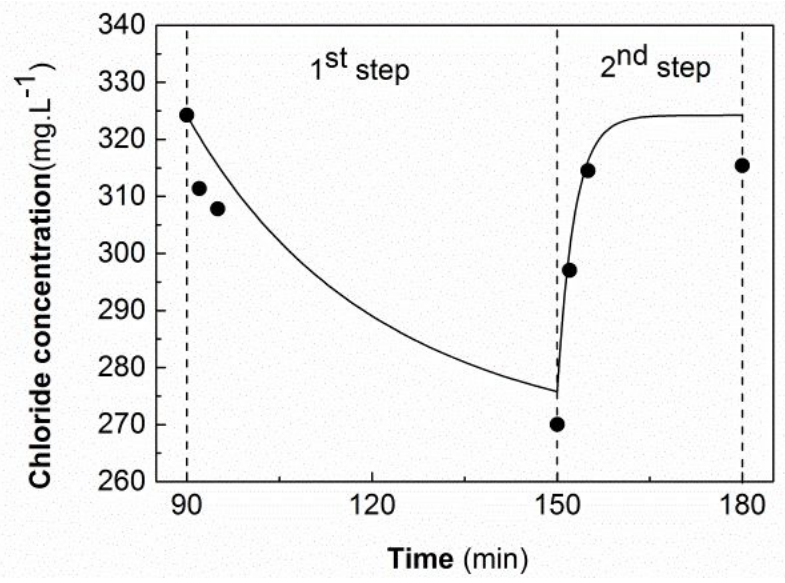

Figure S12. Change in $\mathrm{Cl}^{-}$concentration when the modified DPSC commenced with initial 8. Experimental conditions: the feed solution contained $\mathrm{As}(\mathrm{V})=150 \mu \mathrm{g} \mathrm{L}{ }^{-1} \mathrm{As}(\mathrm{III})$ and $5 \mathrm{mM}$ $\mathrm{NaCl} .+1.2 \mathrm{~V}$ is applied in the $1^{\text {st }}$ step followed by $-1.2 \mathrm{~V}$ in the $2^{\text {nd }}$ step.

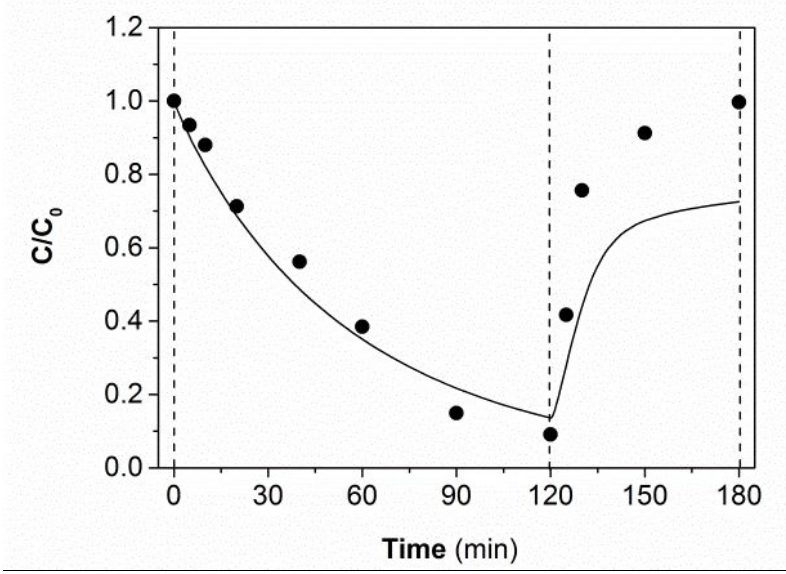

Figure S13. Changes in total arsenic concentration when $150 \mu \mathrm{g} . \mathrm{L}^{-1} \mathrm{As}(\mathrm{III})$ is added to solution at initial $\mathrm{pH} 8$ and $+1.2 \mathrm{~V}$ is applied for 120 min followed by $-1.2 \mathrm{~V}$ for $60 \mathrm{~min}$ using electrochemical cell with electrode area $10 \mathrm{~cm} \times 8 \mathrm{~cm}$. Symbols represent experimental data; lines represent model value. 
Table S2. Parameters for the calculation of the energy cost of DPSC for removal of As(III) during 120-min adsorption in the bigger electrochemical cell

\begin{tabular}{ccc}
\hline Parameters & Unit & Value \\
\hline$U$ & $\mathrm{~V}$ & 1.2 \\
\hline$I_{t}$ & $\mathrm{~A}$ & Figure S14 $^{t}$ \\
\hline $\int_{0}^{t} I_{t} d t$ & A.h & $0.003^{a}$ \\
\hline$V$ & $\mathrm{~m}^{3}$ & 0.00006 \\
\hline $\log \left(\frac{C_{o}}{C_{e}}\right)$ & & $\log (150 / 15)$
\end{tabular}

a: the value of 0.003 represents the integrated current during step 1 over a period of $120 \mathrm{~min}$.

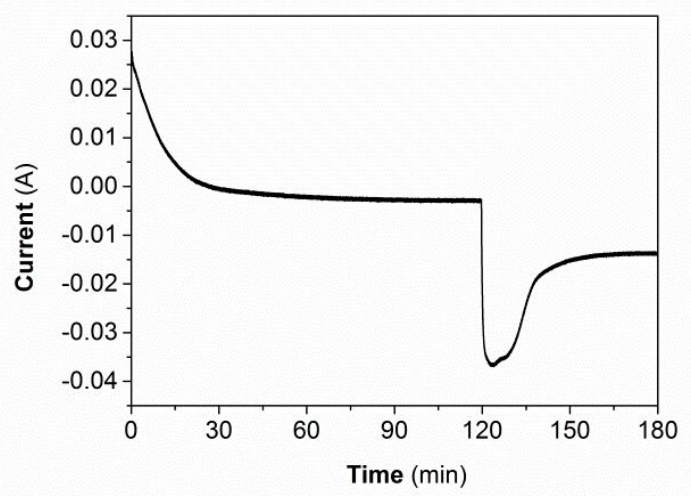

Figure S14. Change in current when the modified DPSC commenced with initial pH 8 . Experimental conditions: the feed solution contained $C_{0}=150 \mu \mathrm{g} \mathrm{L}^{-1} \mathrm{As}(\mathrm{V})$ and $5 \mathrm{mM} \mathrm{NaCl}$. The initial $\mathrm{pH}$ of 8 was controlled by addition of $2 \mathrm{mM} \mathrm{NaHCO}_{3} .1 .2 \mathrm{~V}$ was applied at the first step for $120 \mathrm{~min}$ followed by $-1.2 \mathrm{~V}$ for $60 \mathrm{~min}$ in the electrochemical cell with electrode area $10 \mathrm{~cm} \times 8 \mathrm{~cm}$. 

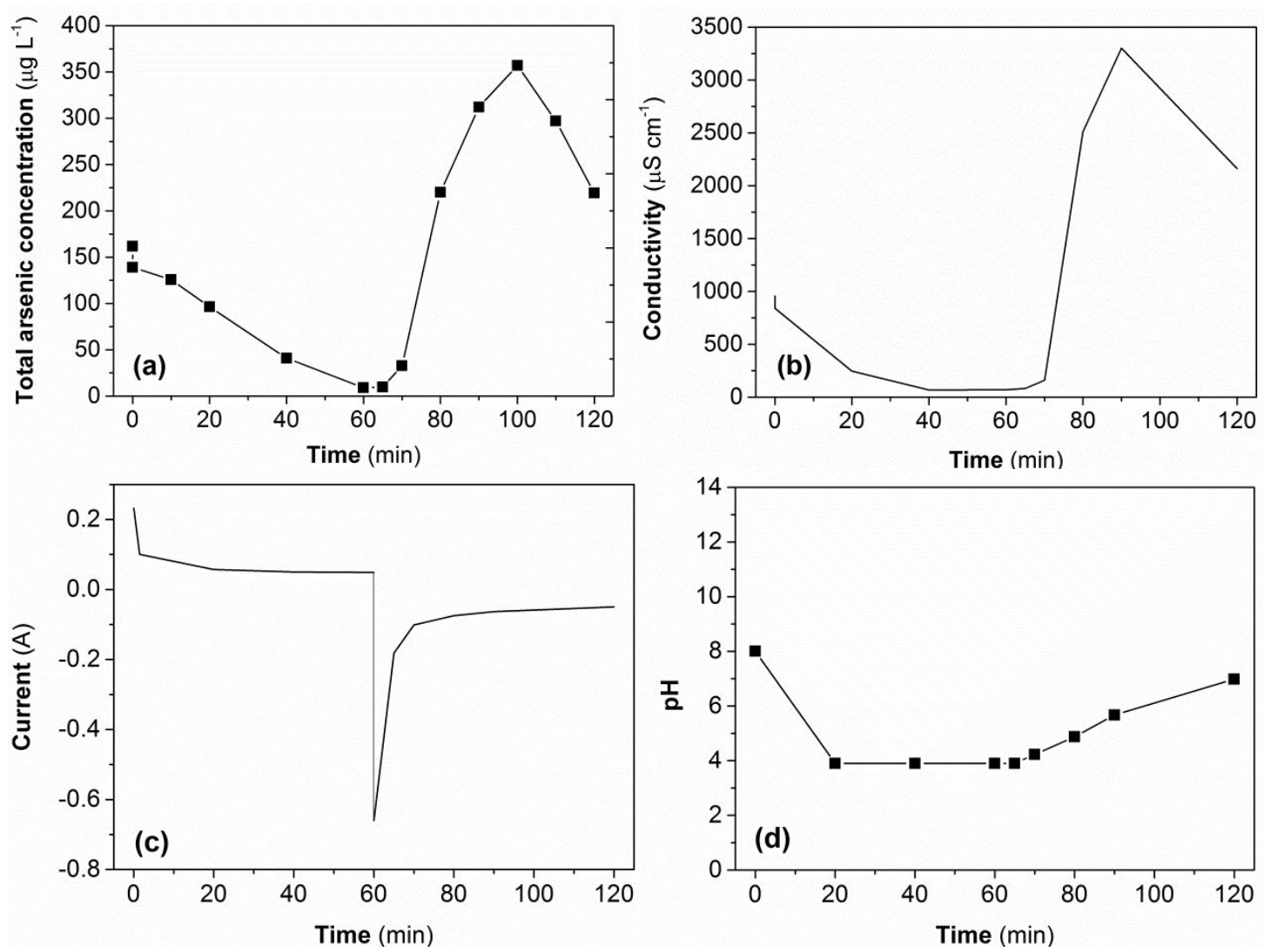

Figure S15. Changes in (a) total arsenic concentration; (b) conductivity; (c) current; (d) pH when $161 \mu \mathrm{g} . \mathrm{L}^{-1} \mathrm{As}(\mathrm{III})$ is added to solution at initial $\mathrm{pH} 8$ and $+1.2 \mathrm{~V}$ is applied for $60 \mathrm{~min}$ followed by $-1.2 \mathrm{~V}$ for $60 \mathrm{~min}$ using electrochemical cell with electrode area $27 \mathrm{~cm} \times 17 \mathrm{~cm}$ shown in Figure S4 in a single-pass mode. 


\section{S3: Detailed description of the kinetic model}

\section{S3.1 Acid-base equilibrium of As(V) and As(III)}

Reactions 1-8 (Table 1) represent the acid-base equilibrium reactions for the various As(III) and $\mathrm{As}(\mathrm{V})$ species. The $\mathrm{p} K_{\mathrm{a}}$ values for these reactions were used as reported in the literature. As mentioned in the main text, we have assumed that the dominant As species in the solution and on the surface are the same and, as such, we have used the same $\mathrm{p} K_{\mathrm{a}}$ values for adsorbed $\mathrm{As}(\mathrm{III})$ and $\mathrm{As}(\mathrm{V})$ species as that used for the dissolved species.

\subsection{Physical adsorption of As(V) and As(III)}

Reactions 9-12 represent the physical adsorption of $\mathrm{As}(\mathrm{V})$ and $\mathrm{As}(\mathrm{III})$ species to the working electrode. The rate constants for reactions 9 and 10 were determined based on the measured $\mathrm{As}(\mathrm{V})$ physical adsorption under varying initial $\mathrm{pH}$ conditions (Figure S4). The rate constants for reactions 11 and 12 were determined based on the best-fit to measured physical adsorption of $\mathrm{As}(\mathrm{III})$ under varying initial $\mathrm{pH}$ conditions (Figure S5). These reactions occur at the first step as well as the second step.

\subsection{Electro-adsorption of $\mathrm{Cl}^{-}$}

Reaction 13 represents the electro-adsorption of chloride ions on the anode with the rate constant for this reaction determined based on the time dependence of $\mathrm{Cl}^{-}$removal in our electrochemical cell (Figure S12).

\subsection{Electro-sorption of As(III) at the anode}

Reaction 14 represents the adsorption of deprotonated As(III) species when a voltage of $1.2 \mathrm{~V}$ is applied. Note that electro-adsorption of the neutral As(III) is expected to be negligible and hence is not included in the model.

\subsection{Electro-sorption of $\mathrm{As}(\mathrm{V})$ at the anode}

Reactions 15-17 represent electro-adsorption of various As(V) species. The rate constants for these reactions were determined based on the measured $A s(V)$ removal under varying initial $\mathrm{pH}$ conditions (Figure 2). As shown, the rate constant for electro-sorption increases with increase in charge of the $\mathrm{As}(\mathrm{V})$ species with completely deprotonated $\mathrm{As}(\mathrm{V})$ species (i.e. 
$\left.\mathrm{AsO}_{4}^{3-}\right)$ adsorbing at a higher rate constant compared to the protonated forms $\left(\mathrm{H}_{2} \mathrm{AsO}_{4}^{-}\right.$and $\mathrm{HAsO}_{4}^{-}$) consistent with the observed effect of $\mathrm{pH}$ on $\mathrm{As}(\mathrm{V})$ electro-adsorption.

\subsection{Electro-desorption of As(III)}

Reaction 18 represents desorption of As(III) from the electrode when the polarity is reversed and $-1.2 \mathrm{~V}$ voltage is applied. The rate constant for these reactions were determined based on the best fit to the measured As(III) concentration released during step 2 in Figure 4.

\subsection{Electro-desorption of $\mathrm{As}(\mathrm{V})$}

Reactions 19-21 represent the desorption of $\mathrm{As}(\mathrm{V})$ when $-1.2 \mathrm{~V}$ voltage is applied. The rate constant for these reactions were determined based on best fit to the measured As(V) concentration released during step 2 in Figures 2 and 4.

\subsection{Anodic oxidation of As(III)}

Reactions 22 and 23 represent the anodic oxidation of dissolved neutral and deprotonated As(III) species respectively near the electrode surface when a potential of $+1.2 \mathrm{~V}$ is applied. Reactions 24 and 25 represents the anodic oxidation of neutral and deprotonated surface As(III) species respectively on the electrode surface when a potential of $+1.2 \mathrm{~V}$ is applied. The rate constant for these reactions were determined based on the best fit to the measured As(III) and $\mathrm{As}(\mathrm{V})$ concentrations when As(III) is added and DPSC is commenced (Figure 4). Note that the rate constant for oxidation of the deprotonated form is higher than for neutral As(III) species which is in agreement with the reported rate constant for these species by various other oxidants such as $\mathrm{H}_{2} \mathrm{O}_{2} \cdot{ }^{1}$

\section{9 $\mathrm{H}_{2} \mathrm{O}_{2}$-mediated oxidation of As(III)}

Reactions 26 and 27 represent the oxidation of $\mathrm{As}(\mathrm{III})$ by $\mathrm{H}_{2} \mathrm{O}_{2}$ that is formed on reduction of $\mathrm{O}_{2}$ when a voltage of $-1.2 \mathrm{~V}$ is applied. The rate constant for these reactions were determined based on the best-fit to the measured As(III) and As(V) concentrations during step 2 (Figure 4). Note that the rate constant for $\mathrm{H}_{2} \mathrm{O}_{2}$-mediated oxidation of $\mathrm{As}$ (III) used here is much lower than the reported rate value. ${ }^{2}$ While the exact reason for this discrepancy is not clear, it may be due to the presence of $\mathrm{H}_{2} \mathrm{O}_{2}$ on or near the surface while $\mathrm{As}(\mathrm{III})$ is present in solution. 


\subsection{Non-Faradaic reactions}

Reactions 28 and 29 represent the formation and consumption of protons respectively during the first and second step respectively as a result of Faradaic reactions. ${ }^{2,3}$ The rate constants for these reactions vary with As species present (i.e. As(III) or As(V)) and $\mathrm{pH}$ as well as with the potential applied and were determined based on the best-fit to measured $\mathrm{pH}$ values during first and second step for different initial $\mathrm{pH}$ values when $\mathrm{As}(\mathrm{V})$ (Figure 2c) and As(III) (Figure 3c) were added. The values of the rate constants used for various initial conditions are provided in Table S3.

Table S3 Rate constants for proton formation/consumption under different conditions.

\begin{tabular}{ccc}
\hline \multicolumn{3}{c}{ Proton formation/consumption during As(V) removal in the first step } \\
\hline $\mathrm{pH} 4$ & $\mathrm{pH} 8$ & $\mathrm{pH} 10$ \\
\hline $1 \times 10^{-7} \mathrm{~s}^{-1}$ & $4 \times 10^{-8} \mathrm{~s}^{-1}$ & $8 \times 10^{-7} \mathrm{~s}^{-1}$ \\
0 & $1.5 \mathrm{~s}^{-1}$ & $240 \mathrm{~s}^{-1}$ \\
\hline Proton formation/consumption during As(V) removal in the second step \\
\hline $\mathrm{pH} 4$ & $\mathrm{pH} 8$ & $\mathrm{pH} 10$ \\
\hline $1 \times 10^{-9} \mathrm{~s}^{-1}$ & $1 \times 10^{-20} \mathrm{~s}^{-1}$ & $1 \times 10^{-20} \mathrm{~s}^{-1}$ \\
$4.73 \times 10^{-3} \mathrm{~s}^{-1}$ & 30 & $300 \mathrm{~s}^{-1}$ \\
\hline Proton formation/consumption during As(III) removal in the first step \\
\hline $\mathrm{pH} 4$ & $\mathrm{pH} 8$ & $\mathrm{pH} 10$ \\
\hline $3 \times 10^{-6} \mathrm{~s}^{-1}$ & $9.5 \times 10^{-8} \mathrm{~s}^{-1}$ & $1.01 \times 10^{-6} \mathrm{~s}^{-1}$ \\
$1 \times 10^{-2} \mathrm{~s}^{-1}$ & 0 & $41 \mathrm{~s}^{-1}$ \\
\hline Proton formation/consumption during As(III) removal in the second step \\
\hline $\mathrm{pH} 4$ & $\mathrm{pH} 8$ & $\mathrm{pH} 10$ \\
\hline $6 \times 10^{-3} \mathrm{~s}^{-1}$ & $800 \mathrm{~s}^{-1}$ & 800 \\
$1 \times 10^{-19} \mathrm{~s}^{-1}$ & $1 \times 10^{-19} \mathrm{~s}^{-1}$ & $1 \times 10^{-19} \mathrm{~s}^{-1}$ \\
\hline
\end{tabular}

\subsection{Faradaic reaction resulting in $\mathrm{H}_{2} \mathrm{O}_{2}$ generation and consumption}

Reactions 30-33 represent $\mathrm{H}_{2} \mathrm{O}_{2}$ formation and decay during the second step as a result of Faradaic reactions. ${ }^{2,4}$ The rate constants for these reactions were determined based on best-fit to the measured $\mathrm{H}_{2} \mathrm{O}_{2}$ concentration in our experimental system (Figure 5a) and were 
independent of solution $\mathrm{pH}$. The rate constants for the Faradaic reactions used are close to the values reported in an earlier study. ${ }^{2}$

\section{References}

1. E. V. i. L'udovit Molmir, Peter Lech, Hydrometallurgy, 1994, 35, 1-9.

2. D. He, C. E. Wong, W. Tang, P. Kovalsky and T. D. Waite, Environmental Science \& Technology Letters, 2016, 3, 222-226.

3. W. Tang, D. He, C. Zhang, P. Kovalsky and T. D. Waite, Water Res, 2017, 120, 229237.

4. T. Kim, J. Yu, C. Kim and J. Yoon, Journal of Electroanalytical Chemistry, 2016, 776, 101-104. 